\title{
$\cong$ NSCRIBING A NEW SPACE \\ Written Expressions of Utopia and Resistance during the Gezi Park Protests in Istanbul
}

\author{
Giustina Selvelli \\ Department of Linguistics and Comparative Cultural Studies, \\ Ca' Foscari University of Venice
}

\begin{abstract}
In this paper I consider examples of urban public inscriptions which appeared during the Gezi Park protests of Istanbul in 2013. I consider them both as a form of expression permitting the creation and circulation of utopian messages of resistance, and as relating to the inclusion of a multiplicity of identities in the protest arena, such as Kurdish, Armenian and LGBT identities. I insist on the role the written word plays in forging a specific and non-exclusivist imaginary of the protest, positioned within complex power dynamics and national narratives. I view the physical presence of specific graphic expressions referencing "marginal identities" as part of a set of revolutionary actions, which demonstrate the importance of written-in spaces and surfaces in processes of "symbolic reterritorialization". This theme emerges as one of the central questions in interpretations of events relating to the Gezi resistance.
\end{abstract}

Keywords: public inscriptions, reappropriation of space, protest, Gezi Park, minorities

\section{The Background to the Gezi Park Protests}

The urban se tng, far from being a mere spatial category, represents a social force which continues to reveal the intact capacity of carrying on and attracting utopian ideals of change (Chodorkoff 2014: 123-127), alongside patterns of socio-political transformation. Undoubtedly, it is through urban mobilizations that political demands are expressed, and the demonstrations which took place in the summer of 2013 - not only those in Turkey but also in countries such as Brazil and Bulgaria - reaffirmed the city as being a privileged setting for social and political action.

The protests surrounding the defense of Gezi park in Istanbul erupted after bulldozers started to cut down the first trees in the only remaining green area in Taksim Square, the most central and symbolic location of the city of Istanbul (Walton 2015: 47-48). The eradication of the trees was justified by the municipality in terms of the need of carry out a shopping mall construction project, which would have become the $49^{\text {th }}$ such project in the city. ${ }^{1}$ The orders came directly from the central government, and the prime minister at that time, Recep Tayyip Erdoğan, fiercely defended the plan of rebuilding the Ottoman-era Taksim Military Barracks to house a shopping mall and luxury apartments. The protests evolved as part of a wider phenomenon after the police raided the environmentalists' encampment in the early morning of the $31^{\text {st }}$ of May. Thousands of people joined the movement and confronted the police repression. ${ }^{2}$

${ }^{1}$ Istanbul is one of the most dense cities in Europe as regards the concentration of shopping malls, which have since come to number approximately one hundred.

${ }^{2}$ For a detailed timeline of the protests see: http://www.hurriyetdailynews.com/timeline-of-gezi-park-protests-aspx?pageID=23 $8 \& \mathrm{nID}=48321 \&$ NewsCatID=341 (accessed 6. 6.2016) 
From the beginning, the demonstrations were marked by a clear positioning against radical changes imposed from above, which were aimed at altering the structure of the city and the everyday life of people who felt a part of it. The suggested Taksim project was symptomatic of intense urban transformations which had occurred since the Adalet ve Kalkinma Partisi (AKP) ("Justice and Development Party") came into power, which have been used to support rhetoric describing Turkey as a "model of democracy" (Tuğal 2013: 154-155) for other countries in the Middle East, and on the economic recovery which has been based on a construction boom. ${ }^{3}$

In addition to ecological concerns, the protests also revealed the discontent of marginalized communities including Armenians, Kurds and LGBT identified persons, thus opposing governmental policies of cultural "homogenization", hidden under the ambiguous identity project of "Neo-Ottomanism" (Fischer Onar 2009; Walton 2015: 49) as well as practices of social discrimination. Among the various voices disagreeing with the government's justifications of economic development and prosperity, there were also Muslim voices, such as representatives of the "Anticapitalist Muslims" movement, who criticized Erdoğan's model of growth from an Islamic point of view. ${ }^{4}$

After a couple of days of dramatic clashes with police, who used massive amounts of tear gas and water cannons with chemical repellents, the protesters, whose numbers had reached the hundreds of thousands, managed to disperse and repulse the security forces, and started a real social experiment in community life. The occupation of Gezi Park turned the area into a space which was temporarily exempt from both hegemonic authorities and police power: for two weeks, the park was shared as an autonomous space for experimenting with new forms of social relations and "public performativity" (Walton 2015: 51), becoming a kind of "city within the city". It was also, however, a kind of "besieged city" that people had to defend (cf. Canetti 1981 [1960]: 27-28). (fig.1 $)^{5}$

Figure I: Daily life at Gezi Park during the occupation (June $2^{\text {nd }}$, 2013).

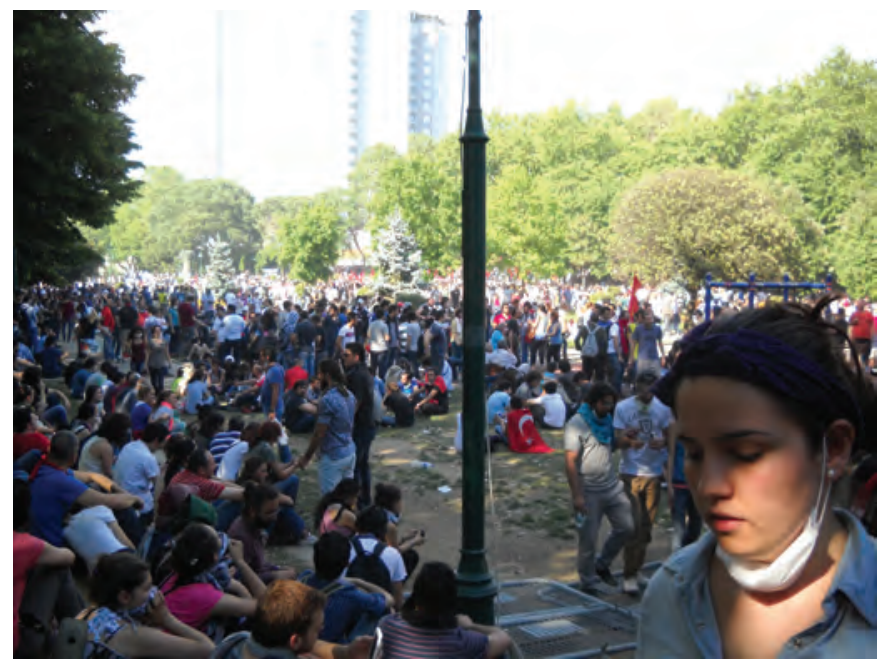

\footnotetext{
${ }^{3}$ Many critics have accused the government of allotting tenders to companies that have close ties to the AK Party, with increasing frequency.

${ }^{4}$ http://www.economist.com/blogs/charlemagne/2013/07/turkish-politics (accessed 6. 6. 2016).

${ }^{5}$ All pictures appearing in this article have been taken by the author.
} 
Gezi Park was an opportunity offering direct experience of sharing, solidarity and cooperation practices, both in the distribution of resources and in managing tasks (Tuğal 2013: 157). Many challenges relating to self-management were posed, and as a consequence two first-aid care centers were created, together with a canteen, a library, a museum of the revolution, a stage for concerts etc., in addition to projects such as a vegetable garden and devising alternative methods for the production of electricity.

By coincidence, I arrived in Istanbul in the early morning of the $31^{\text {st }}$ of May 2013, the day the protests evolved into a bigger movement. I had only planned to stay for a few days but after I realized the importance of the event that was taking place, I decided to stay for four weeks and give myself a chance to witness and take part in this significant, historical moment of "collective utopia". As such, it will become evident that I cannot detach my subjective experience from my enthusiasm towards this event. My involvement in the protests was characterized by a need to break down any existing separation between participating and observing, while practicing what could be described as a form of "militant ethnography", with a personal commitment to the cause (Juris 2007). Nevertheless, my intention is not to reduce the complexity in question to a "romanticised" experience of resistance (Abu Lughod 1990), but to problematize as much as possible the meaning acquired by the public inscriptions as regards the imaginaries present at the protests. These graphical testimonies need to be understood in terms of the relations between several marginal actors and the hegemonic power that, to varying extents, from the founding of the Turkish Republic up until the present day, has condemned them to different forms of "invisibility". There are many points of view that could be chosen in the analysis of such a phenomenon: for example, it is undeniable that one of the most visible "graphic presences" during the protests was a portrait of Mustafa Kemal Atatürk, a constant presence indicating the surfacing of a form of "nostalgia" for the early Republic (Özyürek 2006). We could argue that even in the graphic context, therefore, complex dynamics of power were present, as well as different identity narratives, an undoubtedly contradictory element, which nevertheless proved the validity of the event as an innovative example of a "non-exclusivist setting". In my ethnography, I have decided to position myself in terms of a perspective that tries to give voice to those who are often deprived of the right to speak (and write), insisting on the value of this historical event for putting into practice new, critical strategies, designed to counteract the official, limiting spaces of public operation.

\section{The Importance of Making Public Inscriptions in Reappropriating Space}

As an anthropologist researching the various forms in which the ideological value of writing is expressed in modern societies, ${ }^{6}$ inspired by the work of Giorgio Raimondo Cardona (in particular: 1981, 1986), ${ }^{7}$ I could not remain indifferent to the incredible proliferation of public inscriptions during the Gezi Park protests. Indeed, the "liberated area of action" was transformed into a place of inscription in which the written word took on an incredible role and impact, both visually and practically. This fact was evidenced by crucial reappropriation

\footnotetext{
${ }^{6}$ See for example: Selvelli 2015.

${ }^{7}$ Giorgio Raimondo Cardona (1943-1988) may be considered the founder of the field of the Anthropology of Writing. His greatest contribution is to have highlighted the social, cultural and anthropological aspects of writing systems and written testimonies, a fact that has made them to a certain extent independent from their linguistic dimensions.
} 
strategies which took place in both the graphic context and in communication: a widespread practice of expressing dissent had been inaugurated, free from repression and subjugation. Similar practices could be compared to those which had taken place in Tahrir Square during the Egyptian Revolution in 2011 (Schielke and Winegar 2012; Zakareviciute 2014), and to a certain extent, to those which occurred on the West Bank Wall in Palestine/Israel (Olberg 2013). I decided to document this phenomenon, whilst conscious that all of these written examples were destined to have a fleeting popularity and limited life. My observations are based on a selection of data personally collected during the month of June 2013 not only in Gezi Park but in the whole area of Taksim square and parts of Gümüşsuyu, as well as in many of the surrounding streets, such as Istiklal Caddesi and Siraselviler Caddesi. This was quite an extended area covered by a variety of public inscriptions (graffiti and other forms) which contributed in creating further levels of idealistic signification in the revolutionary context through the use of particular forms of irony and criticism ${ }^{8}$ (Yanık 2015), used as a crucial tool for making a multiplicity of identities visible.

A large amount of the graffiti conveyed jokes and responses to the police attacks and statements by Erdoğan, as a form of "counter-attack" against the violence and repression that the authorities were demonstrating (Yanık 2015). One example was the slogan "Biber gazı cildi güzelleştirir”, which translates as “Tear gas makes your skin more beautiful”, graffitied on the window of the cosmetic shop MAC on the main commercial street Istiklal Caddesi (fig. 2). A second example in the same area stated "Costantino Polis?", making fun of the city's old name (Constantinopolis), which was now the "Police of Costantino" (fig. 3).

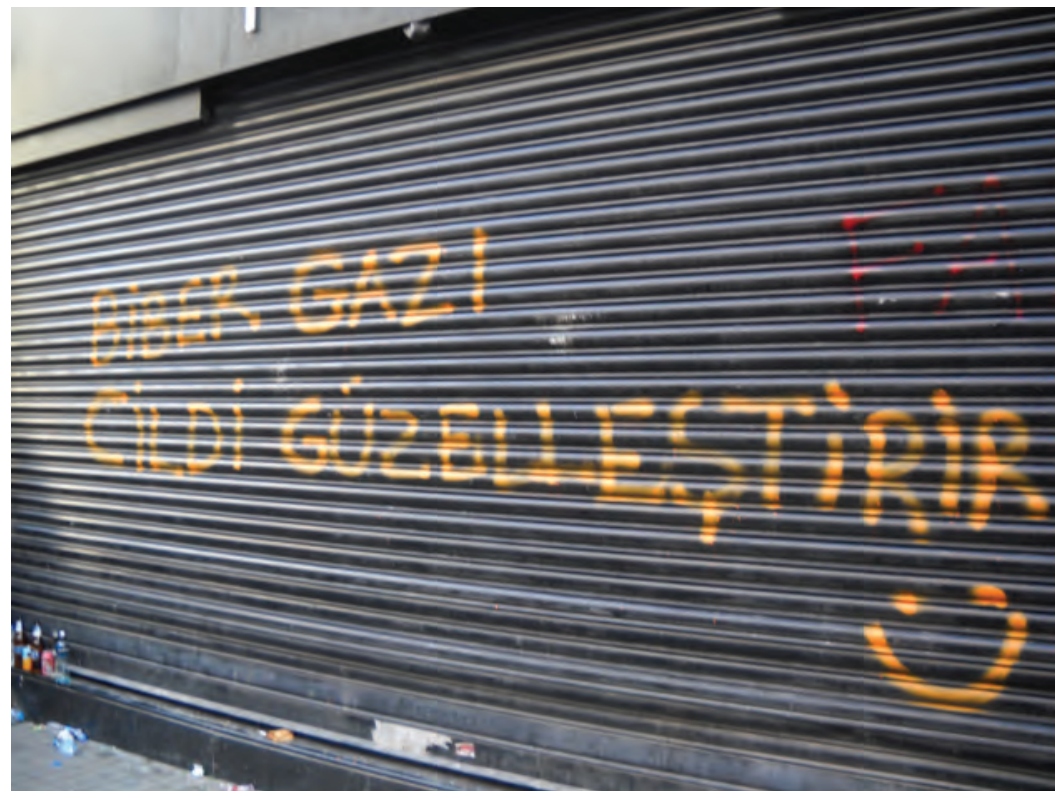

Figure 2: "Tear gas makes your skin more beautiful": Written on the shutter of the cosmetic shop MAC in Istiklal Street (June $\left.2^{\text {nd }}, 2013\right)$.

\footnotetext{
${ }^{8}$ For example, protesters called themselves çapulcu (looters), reappropriating Erdoğan's insult and creating the derivative "chapulling", corresponding to the idea of "fighting for your rights" (see Walton 2015).
} 


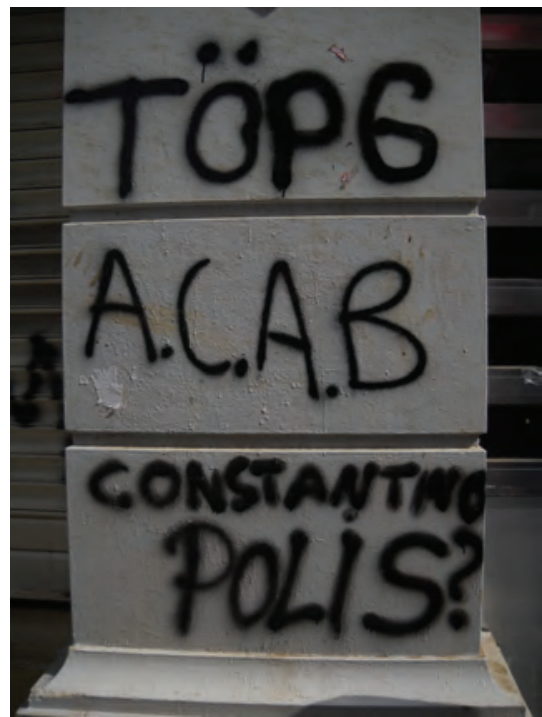

Figure 3: Constantinopolis becomes Costantino polis: the police of Constantino (June $2^{\text {nd }}, 2013$ ).

One very significant example was that of the French Cultural Institute on whose door we could read, in French: "La poesie dans la rue. 1 juin 2013" ("Poetry on the street. 1 June 2013"), expressing a continuity of practices and ideals with the barricades of May 1968 (Bernardoni 2013: 119). ${ }^{9}$ An important role was also played by inscriptions making important cultural references, such as the quote attributed to Karl Marx "Kapitalizm gölgesini satamadığı ağacı keser" ("Capitalism will cut down the tree if it can't sell the shadow"), in Turkish. A very appropriate message, considering the context.

Other examples of public inscriptions communicated the impression of being witnesses to a true revolutionary experience, in a desire to not only attract the attention of a local audience, but also international support and involvement. Messages of international solidarity indeed started to appear on walls and windows, as graffiti claiming support from Norway, Spain and neighboring Bulgaria emerged, where over the same period a big protest movement against government corruption had begun to be organized (Drezov 2013). One night, the news spread of big protests taking place in Brazil, expressing explicit connection and solidarity with the ones of Gezi (Tuğal 2013: 147). A feeling of interconnectedness amidst social awakening across the globe was in the air.

Different forms of public inscriptions also appeared in other languages: banners in Arabic, English, Kurdish, Armenian, and many others. As concerns the Armenian factor in the Gezi Park experience, we have to remember that significantly, and in line with its (ambivalent) "neo-Ottoman" inspiration, the attitude of the government had been to justify the radical renovation project taking place in the Taksim area by referring to "historical memory", promising to reconstruct the military barracks (demolished in 1940), to be used as a shopping mall. The truth is that those same barracks had actually earlier destroyed an Armenian graveyard, a fact that was underlined by the Armenian community of the city during

\footnotetext{
${ }^{9}$ Other graffiti present recalled the French '68 protests, such as: “Under the cobblestones, the beach!", written in Turkish, and taken from the famous slogan "Sous les pavés, la plage!”. I was walking with a French friend late one night when we saw this graffiti, written on the external border of a sidewalk. He said: "I finally understand what this means. And I feel the sand under my feet. This is the sensation of revolution I guess".
} 
the protests through the use of banners and installations. ${ }^{10}$ Furthermore, the architect of the original barracks, which were built in 1806, was Krikor Balian, an Armenian belonging to a famous family of architects serving the Sultans. To remember the architect of the old artillery barracks is not a marginal issue, as his tradition constitutes a part of Turkish and Ottoman history that modern Turkish politicians have invested huge efforts in attempting to erase and forget, or rather "remember, but just in part". This corresponds to the participation of religious minorities, such as Greeks, Assyrians, Jews, but especially Armenians, in the country's cultural, economic and political life. As Tambar argues:

The figure of the minority has been shaped by what I call a negative historicity: negative in the sense of being evacuated from the time and place of historical progression that has characterized the national subject. (Tambar 2016: 34)

Figure 4: The banner of the movement Nor Zartonk, in both Latin and Armenian characters, at Gezi Park (June $4^{\text {th }}, 2013$ ).

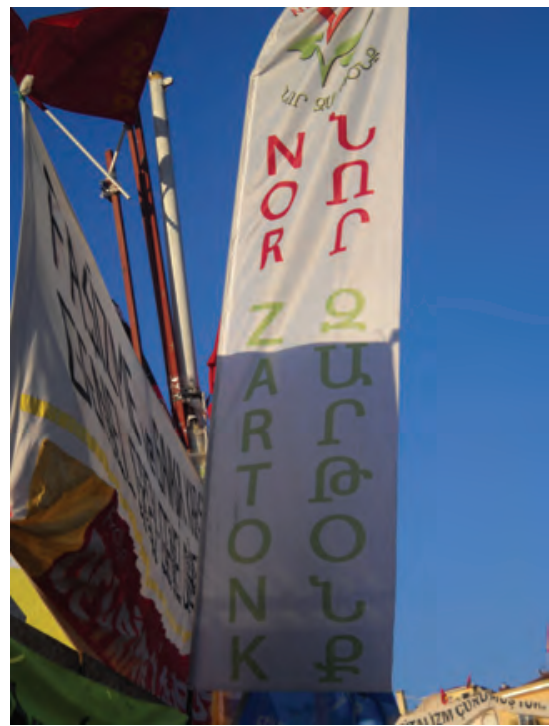

In relation to this, activists from the Nor Zartonk movement ${ }^{11}$ (Armenian for "New Awakening") (fig. 4) raised the slogan "Mezarlığımızı aldınız, parkımızı alamayacaksınız" (in Turkish): “You seized our graveyard, but you can't capture our park!”, marking their presence there from the first day. In relation to the question of Turkish-Armenian relations, during the occupation of the park there was an attempt to erect a monument remembering the one that was placed in Gezi in 1919 dedicated to the memory of the victims of the Armenian genocide, which was then destroyed in 1922. Armenian participation in the protests is thus to a certain extent comparable with the mobilization that followed the murder of the TurkishArmenian journalist Hrant Dink in 2007, an event that is still marked every year on January $19^{\text {th }}$ by people from a variety of cultural and political backgrounds. A group of activists "rebaptized" one of the streets adjacent to the park as "Hrant Dink Caddesi" (Hrant Dink Street), and carried banners saying: "Buradayız Ahparig!": "We are here, Brother!" (the first

\footnotetext{
${ }^{10} \mathrm{http}: / /$ www.newyorker.com/culture/culture-desk/the-armenian-past-of-taksim-square (accessed 6. 6. 2016) and http://www. lemonde.fr/europe/article/2013/06/11/sous-le-parc-occupe-d-istanbul-un-cimetiere-armenien_3428197_3214.html (accessed 6.6.2016).

${ }^{11} \mathrm{http}: / /$ www.norzartonk.org/en/ (accessed 6. 6. 2016).
} 
word in Turkish, the second in Armenian). Another banner was written in Kurdish, and said "Ji bo Hrant, Ji bo dad ê": "For Hrant, For Justice", a message coming from another minority group involved in the cause. We can indeed claim that in Gezi Park, the movement Nor Zartonk, which presents itself explicitly as characterized by anti-systemic struggles, successfully managed to fulfill its aims of defending a space of justice and "an imaginary of a world, of a country which all can inhabit equally, freely and in solidarity". ${ }^{12}$ This was a principle which had also been expressed in other settings before Gezi, for example in the Occupy Movement in Ljubljana 2011 (Razsa and Kurnik 2012), where forms of decision making were characterized by the inclusion of "marginal" voices, and the fight for migrant and minority rights.

Armenians were not the only "minority group" who raised their voice in claiming a new, practical and theoretical space of confrontation with the past and the present: even more visible was the presence of the Kurds. A great deal of graffiti was written in the Kurdish language, including messages referring to the massacre of Roboski (or Uludere massacre) in December 2011, in which Turkish military airplanes attacked a village at the border with Iraq, killing 34 Kurdish civilians, mostly teenagers (Tambar 2016:30-31). At that time over a thousand protesters had gathered in the same Taksim Square, throwing stones at police and smashing vehicles before being dispersed with tear gas and water cannons. The memory of this event was still very fresh in Kurdish consciousness, and it therefore frequently recurred as a graffiti motif on the walls of the streets around the park. Other graffiti slogans appealed for peace, e.g. "Biji aşit̂̀" ("long live peace", in Kurdish) amid a reinvigorated peace process ending the Kurds' decades-long struggle for an independent state, while others were invoking the PKK (Partiya Karkerên Kurdistanê, "Kurdistan Workers' Party") and freedom for the Kurdish people, in Turkish: "Kürt Halkına Özgürlük". (fig. 5)

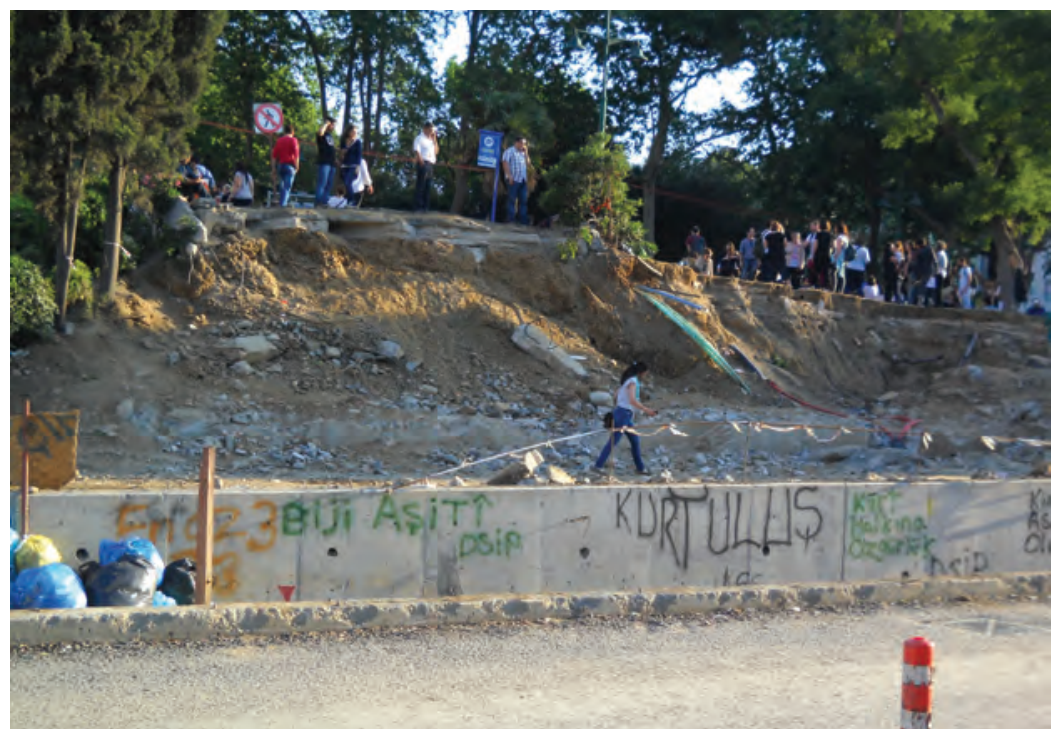

Figure 5:Various graffiti slogans: the first (in green) states: "Biji aşîtî" - "long live peace” (in Kurdish), the second (always in green): “Kürt Halkına Özgürlük” - "Freedom for the Kurdish People” (in Turkish) (June $3^{\text {rd }}, 2013$ ).

${ }^{12}$ http://www.norzartonk.org/en/?page_id=223 (accessed 6. 6. 2016). 
It is important to remember that making public inscriptions in Kurdish in Turkey constitutes an extremely powerful political act, as the Kurdish language has been forbidden for decades in both its written and oral form (Wallerstein 2013; Haig 2004; Saraçoğlu 2011). The Kurdish language has therefore been "invisible" (Haig 2004) for decades and is highly discriminated against to this day: Turkish is the only official language in the country and Article 42 of the Constitution (1982) explicitly prohibits educational institutions from teaching any language other than Turkish as a mother tongue to Turkish citizens (Cassano 2012), a fact which has been heavily criticized, for instance by the Council of Europe in its Progress Report on Turkey in 2005. ${ }^{13}$ Language choices reveal a lot about authors' sense of identity and the audience the messages in question are directed at. Any language choice different from the dominant Turkish, in particular a minor one such as Kurdish or Armenian, represents a way of symbolically reappropriating a space, given there are few chances for such public expression on a day-to-day basis in the country. The intended "audience" of such public inscriptions, thus, was not limited to members of a "protest community", but also included the general public, namely all passers-by who might observe this space in which "unusual", critical and sometimes utopian messages were being transmitted, effectively and with impact. (fig. 6)

Figure 6: Banners at Gezi Park: "Gender identity in the constitution" (in red), "Brotherhood as a forest. Kurds, Turks. Armenians", "Long live the brotherhood of the people" (in white), "Peace" (in green). All written in Turkish (June $4^{\text {th }}, 2013$ ).

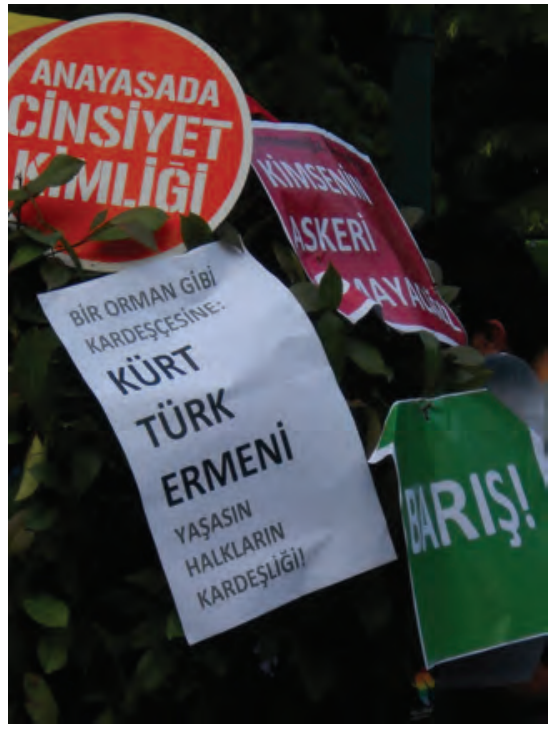

As regards the participation of ethnic minorities, there were also public inscriptions expressing protest and criticism by the Alevi community, a syncretic and heterodox branch of Islam. To some extent, it is linked to Shiism (Paul and Seyrek 2014), historically discriminated against by the Sunni majority (Alemdar and Çorbacığlu 2012). This issue emerged in the decision to name the Third Bridge on the Bosphorus ${ }^{14}$ after the Ottoman Sultan Yavuz Selim, who is considered to have massacred thousands of Alevis in the $16^{\text {th }}$ century.

In addition to ethnic and religious groups' representatives, an important actor in the Gezi resistance was the local LGBT community (see: Grungran et al. 2009), highly discriminated

\footnotetext{
${ }^{13}$ Turkish Constitution, Article 42: "No language other than Turkish shall be taught as mother tongue to Turkish citizens at any institutions of training or education".

${ }^{14}$ Another project at the center of many disputes over environmental and urban development.
} 
against by the AKP's policies. ${ }^{15}$ It is worth pointing out that the protests started in Beyoğlu, the cultural and commercial center of Istanbul, and a neighborhood which has been systematically exposed to the government's urban renewal projects. Such "modernization" processes have aimed to "clean up" Beyoğlu from the influence of so-called "marginal" elements, including representatives of minorities not only from an ethnic, but also from an economic and social point of view (Amnesty International 2011). These marginal elements include sex workers, as well as Kurdish and Roma migrants and those from many countries of Africa, who live in areas such as Tarlabașı, just behind Taksim square. LGBT activists found effective ways to express their dissent, making people more aware of their problems and struggles in the utopian atmosphere of the park through the communicative power of the written word. Gay Pride Week, which had been held in the past under critical circumstances as concerns police repression, was scheduled to take place in the second half of June, and a Transgender March was organized for just a few days after the park evictions took place. The event was a real success and represented a continuation of the protest, which bore witness to a large number of people, much greater than in previous years. Interestingly, during the march, held on June $23^{\text {rd }}$, you could see banners written in Kurdish, including ones representing the "forbidden letters" of the Kurdish alphabet, ${ }^{16}$ as well as in Armenian, with participation once again by Nor Zartonk activists (fig. 7 and 8). On June $30^{\text {th }}$, the Gay Pride Parade attracted almost 100,000 people: the demonstration was joined by Gezi Park protesters, thus making the 2013 Istanbul Pride the biggest one ever held in Turkey. Furthermore, from a gender perspective, Erdoğan's comments and declarations regarding the role of women in the country drew a reaction evidenced in many public inscriptions, and in the strong participation of the feminist movement in the protests. There were some sarcastic banners addressing Erdoğan with the following question: "Benim gibi uç çocuk ister misin?" ("Do you really want three children like me?") (Yanık 2015; Bernardoni 2013). These referred to Erdoğan's statements on the role of women in giving birth to at least three babies so as to ensure the demographic development of the country.

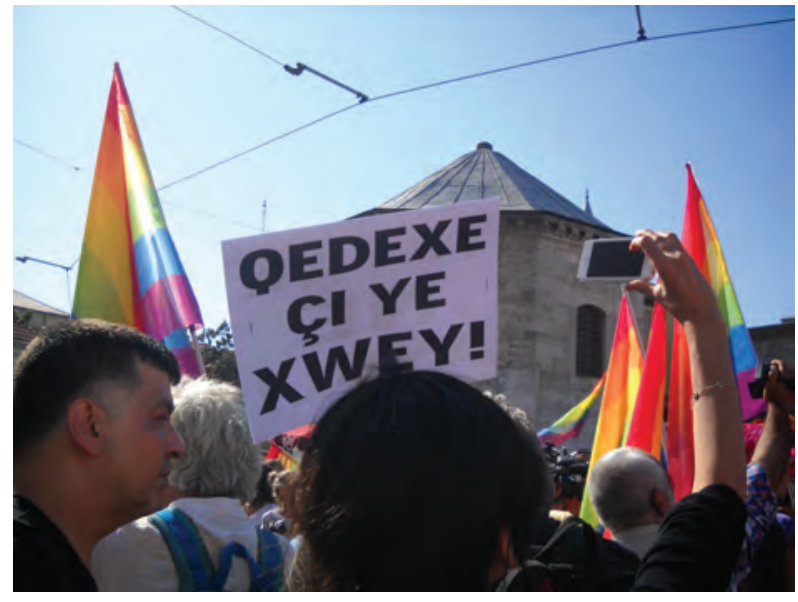

Figure 7:"It is forbidden to be yourself" (in Kurdish), at the Transgender March (June $\left.23^{\text {rd }}, 2013\right)$.

\footnotetext{
${ }^{15}$ On May $29^{\text {th }} 2013$, the AKP rejected a proposal calling for the inclusion of the term "sexual orientation and sexual identity" in the Constitution Conciliation Committee, confirming once again its discriminatory attitude towards such issues (http://www. hurriyetdailynews.com/main-opposition-urges-protection-of-lgbts-ruling-party-calls-them-immoral.aspx?pageID=517\&nID=478 60\&NewsCatID=339, accessed 6.6.2016).

${ }^{16} \mathrm{~h}$ tp://bianet.org/english/minorities/107834-if-your-name-is-kurdish-then-you-cannot-enter-turkey (accessed 6. 6. 2016) and http://bianet.org/english/minorities/115068-journalist-acquitted-a fter-using-kurdish-letters-q-w-and-x (accessed 6. 6. 2016).
} 


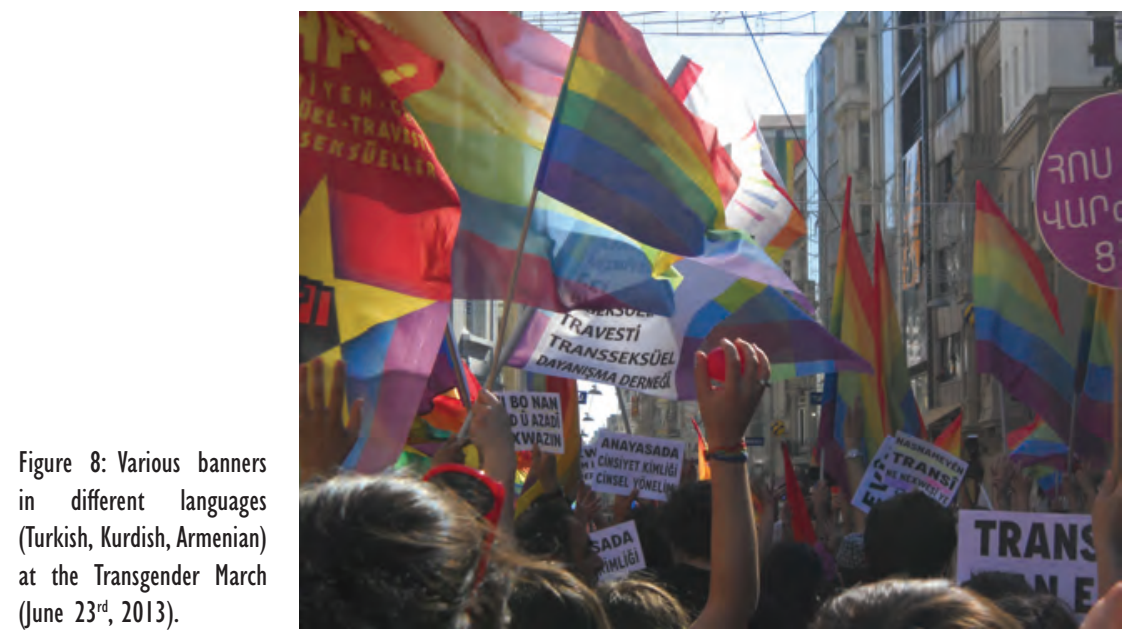

In the stimulating protest setting we can recognize the engagement and interest of the authors of public inscriptions, as well as other activists who expressed their dissent and hopes through a graphic perspective which, in a similar manner to that theorized by Deleuze and Guattari (1975), is sensitive to all which is marginal and "minor". Such highly communicative and "untamable" messages awaken the anthropological gaze, prompting a reflection on what multiplicity symbolizes within social movements taking place in the context of a country enacting oppressive and discriminatory policies towards minorities. They also prove the revolutionary potential of experiencing a daily confrontation with members of other social, political and cultural factions and the feeling of being part of a "local community" (cf. Chodorkoff 2014: 24-26). The privileged expression in the protest graffiti and public inscriptions of "marginalized" ethnic, social or political communities (cf. Faletra 2015) therefore demonstrate attention directed at, and engagement with a so-called "minority" point of view (Deleuze and Guattari 1975). In this case, they became part of a written production which reflected on questions of multiplicity and proposed a vision of the world based on a non-unitary foundation, and rather more on a conception, perhaps utopian (cf. Chodorkoff 2014: 124), of the "cultural multiverse".

\section{Multiple Manifestations of "Graphomania"}

It is an undeniable fact that in Turkey, during the Gezi Park protests, institutional control over the media made itself manifest explicitly, together with the heavy burden of censorship (Iğsız 2013). Nevertheless, through the spontaneous and liberating use of "tools of inscription" - not only electronically but also very publicly and concretely - the ability and strength required to produce autonomous spaces and valid communication channels outside the mainstream were also strongly affirmed (Castells 2015).

Every act of writing has the potential to produce meanings upon reception, and such effects are not reducible to the mere transmission of a written message, but also happen in accordance with the ways in which affirmations are presented to the reader (Fraenkel 2010: 36). In this case, the messages were totally transparent as regards their "symbolism", by virtue of their freshness and irony, as well as the utopian principles with which they were imbued. 
Furthermore, the analysis of writing as applied to the public space brings our attention to the written elements of a specific setting and the way in which inscriptions constitute, manipulate and delimit it. This was the case for the wri ten space of the protests, coinciding with the physical space of the occupation. Writing can be interpreted from both the point of view of the writer and from that of the "consumer" or "reader": while considering these two perspectives we can also find a partial answer to two questions which are of fundamental importance for the anthropology of writing: "What do we do with writing? And what does writing make us do?” (Fraenkel 2010: 42). Curiously, a piece of graffiti painted on a wall suggested one possible answer (fig. 9): "Demokrasi alfabeye borçlu" ("Democracy is indebted to the alphabet").

On this view, burnt police cars and local buses, which had been turned upside down and filled with wrtt en words, became liberated, re-signified objects and media of expression, real manifestations of the urban and "epistemological" change: a different "semiotic space" also required a different approach to knowledge (fig. 10). Any surface became a possible context for inscriptions, the target of a variety of "graphomania" (fig. 11) overwhelmingly conveyed during the days of the protest: vehicles, barricades, together with walls and monuments, and even watermelons like those sold at the park, were engraved with slogans such as: "Tayo Istifa" "Tayo the diminutive form for Erdoğan's name 'Tayyip' - Resignation”), “çapulcu” ("looter”) (fig. 12), all served the same purpose. All such written surfaces continuously a ttracted the visual interest of the reader, and evoked empathy and participation. From the point of view of the observer, ${ }^{17}$ they invited the passer-by, whose "visual sense" had been stimulated, to decipher them.
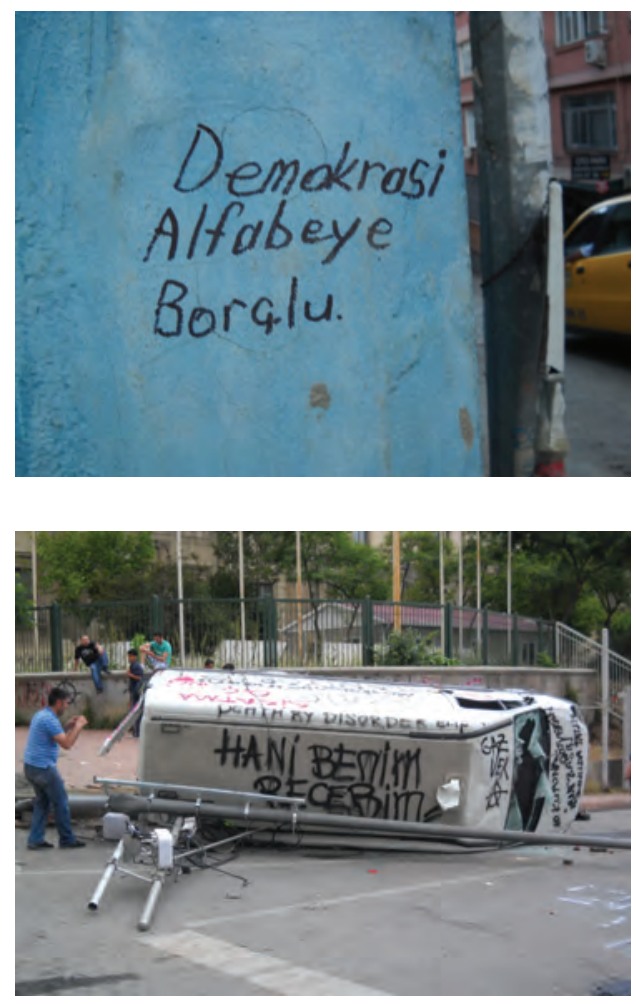

Figure 9: "Democracy is indebted to the alphabet", in Turkish (June $5^{\text {th }}, 2013$ ).

Figure 10: Overturned vehicle, filled with inscriptions (June $3^{\text {rd }}, 2013$ ).

${ }^{17}$ A situation described by Marshall McLuhan (1962) with regard to visual impact of written language. 
Figure II:A girl writing on a wall: "From Taksim..." (June $3^{\text {rd }}, 2013$ ).

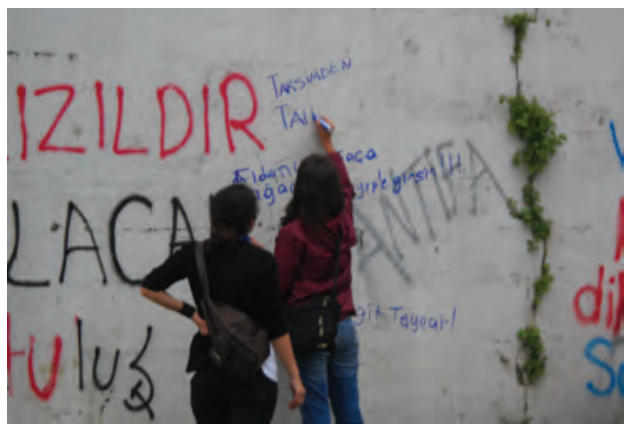

Figure 12: Written watermelons (June $8^{\text {th }}, 2013$ ).

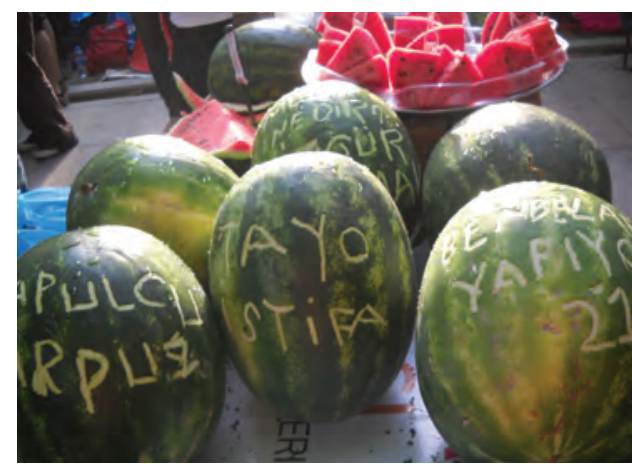

The AKM building (Atatürk Kültür Merkezi) - the former Ataturk Cultural Center, was a particularly interesting case. This building is environmentally friendly, showcasing an energysaving design strategy. Located in Taksim, it has been closed since 2008 and was planned to be demolished as part of the proposed redevelopment plans for the Gezi Park and Taksim Square area, to be replaced with an opera house and a mosque (Iğsız 2013). It acquired a new symbolic presence during the protests, and was likely the most extended writing surface used to express opinions through innumerable banners that were hung on and around it during the protests: a multiplicity of colors and messages (fig. 13). After the police attacked the park and regained control of the whole area, these banners were soon substituted with huge Turkish flags and a giant poster of Atatürk, to symbolize their resuming control of the space and the hegemony of their centralised power.

Figure 13: The facade of the AKM building, covered with banners (June $13^{\text {th }}, 2013$ ).

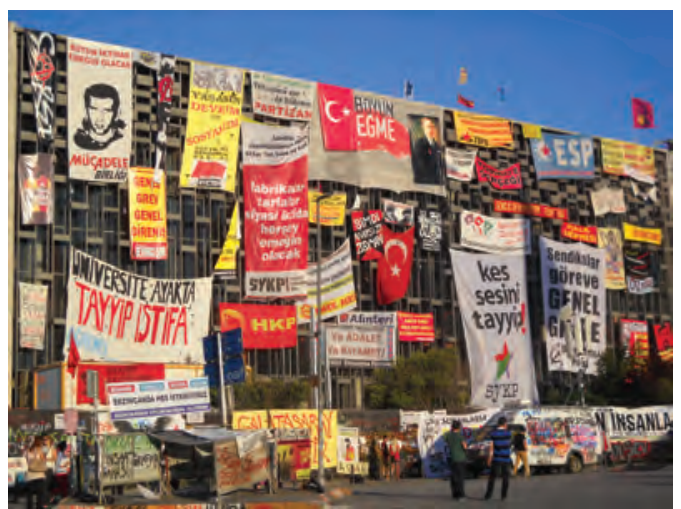


The various forms of public writings described represent paradigms of spatial redefinition, which embody what Bateson (2008 [1972]: 335-337) defines as "context markers", and allow us to conceive of writing as an activity dense in meanings with regard to space. They also reveal how public space continues to facilitate the fostering of transformative actions fundamentally based on communication and exchange. In contrast to social media, which, although being extremely relevant in contexts of revolt (Castells 2015), only manage to produce virtual communities, and depend on the "real world" for the realization of social action, revolutions can only take place in a shared, physical space, where writing messages is a very concrete social activity. Although the production of much of the graffiti was mediated by social media (and it is on social media that they ultimately "survived", after having been wiped from the walls of the city), I believe there is an essential difference between these two contexts of "social writing". Undoubtedly both forms embodied a spontaneous act of expressing dissent, but the "real" one possessed a "multisensorial" potential which made it capable of creating the same space where the "revolution" would take place. In other words, through their actions, people expressed a need to be together in a real space (Tuğal 2013: 157). This enthused proximity combined with the palpable power of the graffiti and public inscriptions, written or glued on the walls, or raised on banners by a multiplicity of people, could provide "visual legitimacy" to such a "utopian setting". In his book The Urban Revolution (1970), Lefebvre imagines an urban utopia characterized by self-determination, individual creativity, and authentic social relationships, opposed to the logics of commodification and bureaucratization associated with ideologies of urbanism. All such utopian components were present at Gezi park, but even more significantly in this context was the fact that the experience tried to unite political subjects whose identities continue to be different and sometimes even antagonistic: from the Kemalist opposition ${ }^{18}$ to the Anticapitalist Muslims, to groups belonging to the radical left and the Halklarm Demokratik Partisi (HDP, "People's Democratic Party") Kurdish party. Solidarity therefore became one of the most visible factors present, which made this resistance comparable to the experience of a commune.

Specific changes in temporal as well as spatial perception were also made possible by virtue of the public inscriptions' creative force: Taksim square and Gezi Park were not the same places as before the protests, and there was a need to create (and define) meaningful points of reference in the collective consciousness: street names, first-aid centers, "border check points" and barricades (fig. 14). These all represented the coordinates of a new, liberated area of action and change: a self-managed space, characterized by the complete absence of the state, and a laboratory testing ideas relating to a different, possible Turkey. A country inspired by a more genuine relationship with its past, struggling in the present for its unsilenceable potential future.

${ }^{18}$ Corresponding to the CHP, Cumhuriyet Halk Partisi ("Republican People's Party"). 
Figure 14: Written barricades: "Hükümet istifa" - "Government resignation" (June 4th, 2013).

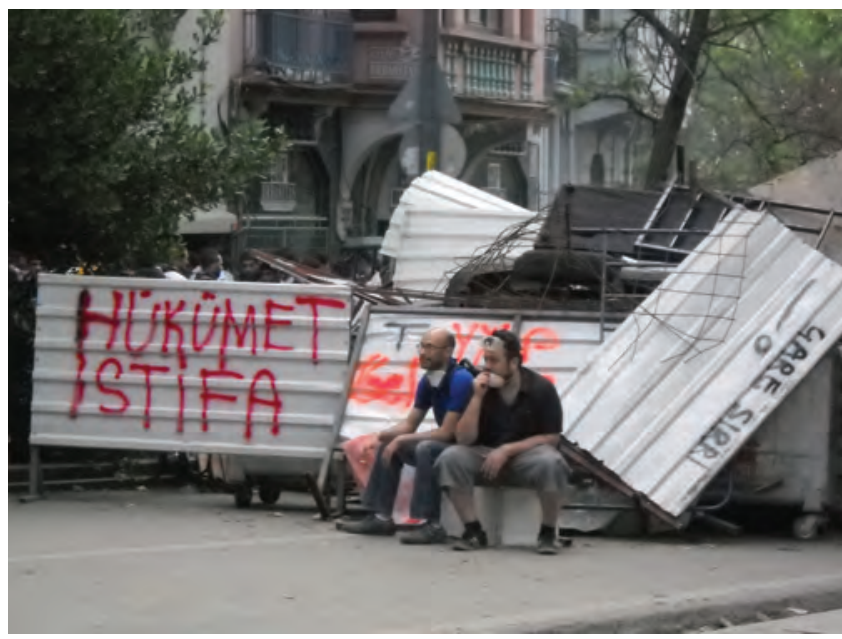

In relation to this, it is worth remarking the references made in those days to a crucial figure of Turkish culture such as the poet Nazım Hikmet. June $3^{\text {rd }}$ (the second day of the "liberation" of Gezi) marked the fiftieth anniversary of the poet's death while exiled in Moscow in 1963. Hikmet has always represented a very powerful symbol of resistance in the country, because of his troubled life as a victim of political repression and marginalization, due to which he spent many years imprisoned before leaving the country, never able to return. ${ }^{19}$ Some of the public inscriptions referenced his memory: "Haziranda ölmek zor" ("It is difficult to die in June”), “3 Haziran 1963" ("the $3^{\text {rd }}$ of June 1963”), "Nazım Usta” ("Nazım Master”), and "Nazım Hikmet vatan hainliğine devam ediyor hala" ("Nazim Hikmet is still betraying his fatherland"). (fig. 15 and 16)

Figure 15: Different writings remembering Nazım Hikmet (in Turkish): "It is difficult to die in June", "June 3rd 1963", "Nazım Master" (June 3rd 2013).

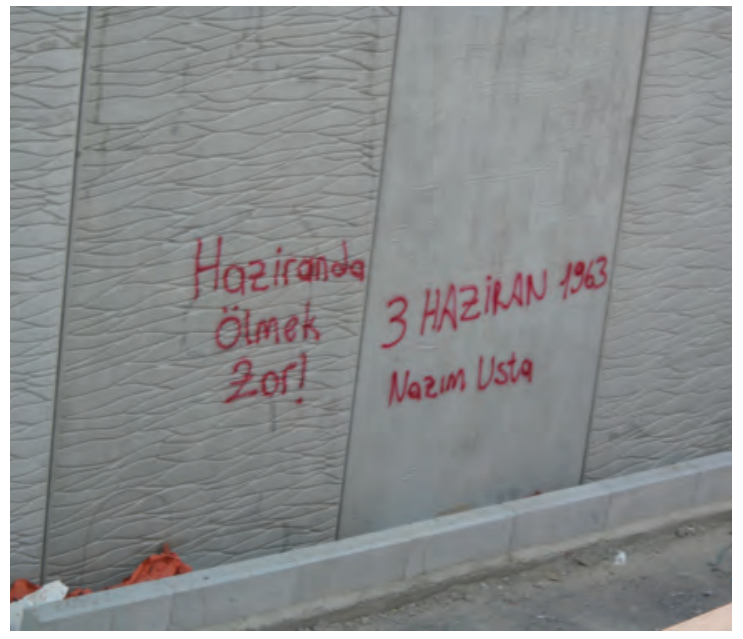

\footnotetext{
${ }^{19}$ Hikmet always nourished a deep sensitivity towards questions of marginal actors. For example, in his work The Epic of the Turkish Independence War (in Turkish Kurtuluş Savaşı Destamı), he narrated the war of independence from the perspectives of the ordinary people of Anatolia, challenging the official historiography of the state (Hikmet 1965).
} 


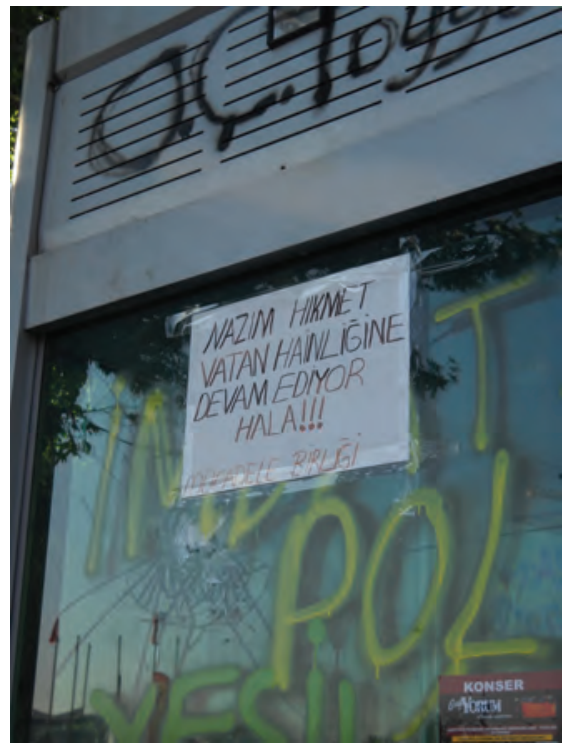

Figure 16:"Nazım Hikmet is still betraying his fatherland" (June 3rd 2013).

His famous poem "Ceviz ağacı" ("The Walnut Tree”) took on a prophetic turn, offering intense inspiration to the guardians of Gezi Park. Hundreds of people were reclaiming the verses of the poem to defend the trees, a perfect way to pay tribute to his memory. Many placards also quoted this poem, sometimes changing the original "Gülhane Park" to "Gezi Park" for obvious reasons:

(...) My leaves are my eyes, I look in amazement

I watch you with one hundred thousand eyes, I watch Istanbul

Like one hundred thousand hearts, beat, beat my leaves

I am a walnut tree in Gülhane Park

Neither you are aware of this, nor the police. ${ }^{20}$

\section{REFERENCES}

Amnesty International. 2011. 'Not an Illness Nor a Crime'. Lesbian, Gay, Bisexual and Transgender People in Turkey Demand Equality. London.

Abu Lughod, Lila 1990. “The Romance of Resistance. Tracing Transformations of Power through Bedouin Women”. American Ethnologist 17/1: 41-55. [https://doi.org/10.1525/ae.1990.17.1.02a00030]

Alemdar, Zeynep and Rana Birden Çorbacıoğlu. 2012. "Alevis and the Turkish State”. Turkish Policy Quarterly 10/4: 117-124.

Bateson, Gregory. 2008. Verso un'ecologia della mente [or. ed. Steps to an ecology of mind, 1972]. Milano: Adelphi.

Bernardoni, Moira. 2013. "I graffiti della resistenza di Gezi: riappropriazione, comunicazione e ironia”. In Gezi Park. Coordinate di una rivolta. Moira Bernardoni, Fazıla Mat, Pietro Maestri, Lea Nocera, Fabio Ruggero and Fabio Salomoni, eds. Roma: Alegre, $105-133$.

Canetti, Elias. 1981. Massa e Potere [or. ed. Masse und Macht, 1960]. Milano: Adelphi.

Cardona, Giorgio Raimondo. 1981. Antropologia della scrittura [The Anthropology of Writing]. Torino: Utet.

Cardona, Giorgio Raimondo. 1986. Storia universale della scrittura [Universal History of Writing]. Milano: Mondadori.

Cassano, Joe. 2012. "Turkey. Kurds And The Constitution". Alakhbar, 25 May, http://english.al-akhbar.com/node/7685 (accessed 6. 6. 2016).

Castells, Manuel. 2012. Networks of Outrage and Hope. Social Movements in the Internet Age. Cambridge - Malden: Polity Press.

\footnotetext{
${ }^{20}$ From the website http://www.siir.gen.tr/siir/n/nazim_hikmet/the_walnut_tree.htm (accessed 6. 6. 2016), translated by Gün Gencer. The orignal version in Turkish: "Yapraklarım gözlerimdir, şaşarak bakarım/ Yüz bin gözle seyrederim seni, İstanbul'u/ Yüz bin yürek gibi çarpar, çarpar yapraklarım/ Ben bir ceviz ağacıyım Gülhane Parkı’nda/ Ne sen bunun farkındasın, ne polis farkında”.
} 
Chodorkoff, Dan. 2014. The Anthropology of Utopia. Essays on Social Ecology and Community Development. Porsgrunn: New Compass. Constitution of Turkey. 1982. Part II (in English), http://www.hri.org/docs/turkey/con2c.html (accessed 6. 6. 2016).

European Commission against Racism and Intolerance (ECRI). 2005. Progress Report on Turkey. http://ec.europa.eu/transparency/regdoc/rep/2/2005/EN/2-2005-1426-EN-1-0.Pdf (accessed 6. 6. 2016).

Deleuze, Gilles and Felix Guattari. 1975. Kafka. Pour une littérature mineure. Paris: Les éditions de Minuit.

Drezov, Kyril. 2013. "A Neighbour in Turmoil. Two Waves of Popular Protest in 2013 Bulgaria”. In Reflections on Taksim - Gezi Park Protests in Turkey. Bülent Gökay and Ilia Xypolia, eds. Staffs: Keele University, Keele European Research Centre, Southeast European Series, 52-57.

Faletra, Marcello. 2015. Graffiti. Poetiche della rivolta. Milano: Postmedia books.

Fisher Onar, Nora. 2009. "Neo-Ottomanism, Historical Legacies, and Turkish Foreign Policy”. EDAM/ German Marshall Fund Working Paper Series 2009 (3)

Fraenkel, Beatrice. 2010. "Writing Acts. When Writing is Doing”. In The Anthropology of Writing. Understanding Textually Mediated Worlds. David Barton and Uta Papen, eds. London: Continuum, 33-46.

Grungras, Neil, Rachel Levitan and Amy Slotek. 2009. “Unsafe Haven. Security Challenges Facing LGBT Asylum Seekers and Refugees in Turkey". Praxis 24: 41-61.

Haig, Geoffrey. 2004. "The Invisibilisation of Kurdish. The Other Side of Language Planning in Turkey”. In Die Kurden. Studien zu ihrer Sprache, Geschichte und Kultur. Stephan Conermann and Geoffrey Haig, eds. Schenefeld: EB-Verlag, 121-150.

Hikmet, Nazım. 1965. Kurtuluş Savaşı Destanı. İstanbul: Yön Yayınları.

Iğsız, Asl. 2013. "Brand Turkey and the Gezi Protests. Authoritarianism, Law and Neoliberalism”. Jadaliyya, 12 July, http://www. jadaliyya.com/pages/index/12907/brand-turkey-and-the-gezi-protests_authoritarianis (accessed 6. 6. 2016).

Juris, Jeffrey S. 2007. "Practicing Militant Ethnography with the Movement for Global Resistance in Barcelona". In Constituent Imagination. Militant Investigations, Collective Theorization. Stevphen Shukaitis and David Graeber, eds. Oakland - Edinburgh - West Virginia: AK Press, 164-176.

Lefebvre, Henri. 1970. La révolution urbaine. Paris: Gallimard.

McLuhan, Marshall. 1962. The Gutenberg Galaxy. The making of typographic man. Toronto: University of Toronto Press.

Olberg, Steven T. 2013. Political Graffiti on the West Bank Wall in Israel/ Palestine. Lewiston: Edwin Mellen Press.

Özyürek, Esra. 2006. Nostalgia for the Modern. State Secularism and Everyday Politics in Turkey. Durham: Duke University Press. [https://doi.org/10.1215/9780822388463]

Paul, Amanda and Demir Murat Seyrek. 2014. Freedom of Religion in Turkey. The Alevi Issue. Brussels: European Policy Centre, http://www.epc.eu/pub_details.php?pub_id=4093 (accessed 6.6.2016).

Razsa, Maple and Andrej Kurnik. 2012. "The Occupy Movement in Žižek's Hometown”. American Ethnologist 39/2: 238-258. [https://doi.org/10.1111/j.1548-1425.2012.01361.x]

Saraçoğlu, Cenk. 2011. Kurds of Modern Turkey. Migration, Neoliberalism and Exclusion in Turkish Society. London - New York: Tauris Publishers.

Schielke, Samuli and Jessica Winegar. 2015. "The Writing on the Walls in Egypt”. Middle East Report 42 (Winter), http://www.merip. org/mer/mer265/writing-walls-egypt (accessed 6. 6.2016).

Selvelli, Giustina. 2015. "Alphabet and Writing in the Armenian Diaspora of Plovdiv. Anthropological and Sociolinguistic Perspectives". Mediterranean Language Review 22: 157-188.

Tambar, Kabir. 2016. "Brotherhood in Dispossession. State Violence and the Ethics of Expectation in Turkey". Cultural Anthropology 31/1: 30-55. [https://doi.org/10.14506/ca31.1.03]

Tuğal, Cihan. 2013. "Resistance Everywhere. The Gezi Revolt in Global Perspective". New Perspectives on Turkey 49: 157-172. [https://doi.org/10.1017/S0896634600002077]

Wallerstein, Immanuel. 2013. “Turkey. Dilemma of the Kurds”. In Reflections on Taksim - Gezi Park Protests in Turkey. Bülent Gökay and Ilia Xypolia, eds. Keele University: Journal of Global Faultlines, 31-32.

Walton, Jeremy F. 2015. "Everyday I'm Çapulling! Global Flows and Local Frictions of Gezi". In "Everywhere Taksim". Sowing the Seeds for a New Turkey at Gezi. Isabel David and Kumru F. Toktamış, eds. Amsterdam: University of Amsterdam Press, 45-57.

Yanık, Lerna. 2015. "Humour as Resistance? A Brief Analysis of the Gezi Park Protest Graffiti". In "Everywhere Taksim". Sowing the Seeds for a New Turkey at Gezi. Isabel David and Kumru F. Toktamış, eds. Amsterdam: University of Amsterdam Press, 153-184.

Zakareviciute, Ieva. 2014. "Reading Revolution on the Walls. Cairo Graffiti as an Emerging Public Sphere". Hemispheres 29/1: 109-127.

http://bianet.org/english/minorities/107834-if-your-name-is-kurdish-then-you-cannot-enter-turkey (accessed 6. 6. 2016).

http://bianet.org/english/minorities/115068-journalist-acquitted-a fter-using-kurdish-letters-q-w-and-x (accessed 6. 6. 2016).

http://mondediplo.com/blogs/gezi-park-whose-history-is-erdogan-respecting (accessed 6. 6. 2016).

http://www.economist.com/blogs/charlemagne/2013/07/turkish-politics (accessed 6. 6. 2016).

http://www.hurriyetdailynews.com/main-opposition-urges-protection-of-lgbts-ruling-party-calls-them-immoral.aspx?pageID=51 $7 \& \mathrm{nID}=47860 \&$ NewsCatID=339 (accessed 6. 6. 2016).

http://www.hurriyetdailynews.com/timeline-of-gezi-park-protests-aspx?pageID=238\&nID=48321\&NewsCatID=341 (accessed 6. 6. 2016).

http://www.lemonde.fr/europe/article/2013/06/11/sous-le-parc-occupe-d-istanbul-un-cimetiere-armenien_3428197_3214. html (accessed 6. 6. 2016)

http://www.newyorker.com/culture/culture-desk/the-armenian-past-of-taksim-square (accessed 6. 6. 2016). 


\section{Upisivanje novog prostora. Pisani izrazi utopije i otpora tijekom prosvjeda u parku Gezi u Istanbulu}

\section{Sažetak}

U ovom radu razmatram primjere urbanih javnih natpisa koji su se pojavili za vrijeme prosvjeda u parku Gezi u Istanbulu 2013. godine. Istodobno ih smatram oblikom izražavanja koji omogućava nastanak i cirkuliranje utopijskih poruka otpora i načinom uključivanja mnoštva identiteta u prosvjednom prostoru, poput kurdskog, armenskog i LGBT identiteta. Inzistiram na ulozi koju pisana riječ ima u stvaranju specifičnog i neisključujućeg imaginarija prosvjeda, smještenog u kompleksnoj dinamici moći i nacionalnih narativa. Fizičku prisutnost određenih grafičkih izražaja koji se odnose na "marginalne identitete" vidim kao niz revolucionarnih akcija koje ukazuju na važnost upisanih prostora i površina u procesima "simboličke reteritorijalizacije". Ova se tema pojavljuje kao jedno od središnjih pitanja tumačenja zbivanja vezanih uz otpor u Gezi.

Ključne riječi: javni natpisi, reaproprijacija prostora, prosvjed, park Gezi, manjine 